\title{
Environmental Challenges and the Measures Taken by the BMDA for Sustainable Agriculture and Environment in the Barind Tract, North-West of Bangladesh
}

\author{
Mohammad Selim Reza ${ }^{1, ~ *, ~ M o h a m m a d ~ I q u e b a l ~ H o s s a i n ², ~ M o h a m m a d ~ E l i a s ~ H o s s a i n ~}{ }^{1}$ \\ ${ }^{1}$ Department of Economics, University of Rajshahi, Rajshahi, Bangladesh \\ ${ }^{2}$ Barind Multipurpose Development Authority, Rajshahi, Bangladesh
}

Email address:

msreza06@ru.ac.bd(M. S. Reza), iquebal_hossain@yahoo.com(M. I. Hossain), eliaseco@ru.ac.bd(M. E. Hossain)

${ }^{*}$ Corresponding author

To cite this article:

Mohammad Selim Reza, Mohammad Iquebal Hossain, Mohammad Elias Hossain. Environmental Challenges and the Measures Taken by the BMDA for Sustainable Agriculture and Environment in the Barind Tract, North-West of Bangladesh. International Journal of Agricultural Economics. Vol. 5, No. 5, 2020, pp. 197-209. doi: 10.11648/j.ijae.20200505.17

Received: August 17, 2020; Accepted: August 31, 2020; Published: September 29, 2020

\begin{abstract}
Barind Tract, located in the North-West region of Bangladesh is a drought prone water stressed area. Barind Multipurpose Development Authority (BMDA) has made this desert like zone into a granary one through various activities including irrigation as major. Now, the agricultural pattern, cropping intensity, methods of cultivation, crop variety and yields - all show a positive change. The BMDA has significant impacts of reducing environmental impact as well as changing the living standard and socio-economic conditions of the rural people in Barind Tract. The present study aims to find out the environmental challenges faced by the farmers in the Barind Tract and the mitigation measures took by the BMDA as a large development partner for the sustainable development in the Barind Tract. As on environmental issue respondent in Puthia, Paba and Godagari zones identifies that low rainfall, extraction of ground water by DTWs (Deep Tubewells) and STWs (Shallow Tubewells), very thin flow of water in the rivers and also losses of groundwater from the aquifer to the river as base flow during dry season are the major causes of the scarcity of ground water in the Barind Tract. Droughts, high temperatures, less rainfalls, cyclones and thunderstorms and lightning also have been identified by respondents as the natural hazards affect their crop production and daily livelihood. To reduce the environmental challenges, no more new DTWs are being installed by BMDA (though private initiatives are still going on), emphasize on using more surface water from rivers and canals through low lift pumps, community based tree plantation programs in the project area, use renewable energy produced by solar panels and re-excavate canals and ponds for conservation of surface water. This study suggests that scientific assessment of groundwater resources with zoning for proper planning, increase augmentation of surface water as well as harvesting of rain water, crop zoning, increase cultivation of low water consuming crops and enhance groundwater recharge are now the demand of time for the study area.
\end{abstract}

Keywords: Agriculture, Environmental Challenges, Socio-economic Status, Sustainable Development

\section{Introduction}

Barind Tract is geographically located in the greater part of Rajshahi, Dinajpur, Rangpur and Bogra districts of Bangladesh and the Indian territorial Maldah District of West Bengal [7] Barind Tract is a physiographic unit located in north-western part of Bangladesh having gross area of 7,727 sq km [40]. The hard red soil, typical dry climate with comparatively high temperature and less rainfall of these areas are very significant in comparison to that of the other parts of the country [7]. The general scenario of these regions was sun-burn hot tempered high and low land and the cactus, babla (Vachellianilotica), herb and the palm trees were seen here and there [1] Rainfall of these areas varies from about $1500 \mathrm{~mm}$ to $2000 \mathrm{~mm}$ and temperature ranges between 8 degrees Celsius to 44 degrees 
Celsius [2]. Before implementing the projects of Barind Multipurpose Development Authority (BMDA), the farmers of these regions used to cultivate only one crop per year since the agricultural activities were heavily dependent on rainfall and the production of crops was hampered if the rainy season was not come in the right time. Due to this reason, people of these areas were too poor and regularly migrated to other places for searching job. In 1985, the engineers of Bangladesh Agriculture Development Corporation (BADC) designed a special type of deep tubewell (inverted designed deep tubewell) and started irrigation by using underground water. Under BADC, a project named Barind Integrated Area Development Project (BIADP) was taken for the development of Barind Tract which covered 15 Upazilas (sub-district) of Rajshahi, Chapainawabganj and Naogaon districts [41]. To speed up the implementation of the development project, a separate authority has been created named Barind Multipurpose Development Authority (BMDA) on $15^{\text {th }}$ January 1992 under the Ministry of Agriculture, Bangladesh [7]. Later, such projects have been broadly expanded to cover the whole Rajshahi and Rangpur divisions consisting of 16 districts with a net cultivable area of about 2.6 million hectares [6]. The BMDA has set up over 11,000 deep tubewells since 1985 as well as re-activated around 4,000 existing ones, meaning that the total numbers of operating deep tubewells are around 15,000 for irrigation [9]. Since 1985, BMDA has completed 33 development projects in the Barind Tract [7]. These projects included the development activities like irrigation facility, construction of rural roads, supply of drinking water to the villagers from the project deep tubewells (DTWs), electrification of irrigation equipment and agro-based industries, producing seed and supply to the farmers, afforestation, increasing use of surface water, developing pre-paid meter system in irrigation management, creating employment opportunities, arranging training for the farmers and re-excavation of ponds and canals [8]. These development projects have significant impact in changing living standard and socioeconomic conditions of the rural people in the Barind Tract area [42].

Availability of irrigation in Barind tract has revolutionized its agriculture, since the irrigation facility increased the cropping intensity (from $117 \%$ in 1985 to $262 \%$ in 2018), crop diversification, crop production as well as increasing agri-employments. But at the same time, groundwater level has been successively falling all over the region due to excessive withdrawal of groundwater for irrigating the large area of crop lands all-round the year with some other reasons like less rainfall, hot temperatures, thick top clay that restricts natural recharge [16], low water flow in the major rivers in the dry season [41] and also losses of groundwater from aquifer to the river due to lowering of river water level during dry season $[17,18]$. It is observed the successive depletion of groundwater level with expansion of groundwater irrigation in Barind Tract from mid-1960s to 2010 in the context of Tanore Upazilla, which is located in severely drought prone area of the northwest Bangladesh [42]. The ratio of groundwater to surface water use is much higher in the north-western districts of Bangladesh compared to other parts of the country [11]. Most of the rivers including Padma, Mohananda and Teestain the Barind Tract are drying during the dry season and made the people completely dependent on groundwater $[25,26]$. The researchers have shown that groundwater level in some areas falls between $5-10 \mathrm{~m}$ in dry season and most of the hand tubewells and shallow tubewells (STWs) get failed to lift sufficient water. The ground water depletion problem in the northwestern part of Bangladesh is severe because this part is free from seasonal flooding [12]. Only source of recharging ground water aquifer in this area is rainfall, but rainfall is also lowest here compared to other regions of the country.

The depletion process is also accelerating due to water withdrawn from major rivers by up streams countries [42]. Due to low level of water of these rivers, the underground water flows or transfer from main land areas to the rivers. With the cessation of rainfall (a major source of surface water), recharging groundwater also gradually stops and about $24 \%$ of the annual recharged water is lost by discharge into the khals (canals), streams, low-lying areas and rivers and for evapotranspiration and other uses before the irrigation season starts, which results is the scarcity of groundwater in the Barind area [10]. It is found that in the Barind Tract, moisture depletion starts from late October and there exists no available soil moisture by the end of December due to a short monsoon period [19, 20]. Due to recent declination of groundwater level during the dry season, drought becomes a common phenomenon in northwest Bangladesh which has posed a major threat on irrigated agricultural system $[25,26]$. In the last 40 years, the area suffered eight major droughts episodes. Recurrent droughts and use of modern irrigation equipment like Shallow Tubewells (STWs), Deep Tubewells (DTWs) has made the people more dependent on ground water irrigation. The experts explained that ground water levels have declined substantially during the last decade causing threat to the sustainable use of water for irrigation in this region impacting other sectors too [20]. People of Rajshahi district convert their crop land into forest and fruits garden [24]. Lack of proper knowledge, indiscriminate installation of pumps and non-availability of modern technologies for efficient use of water are the major causes of inappropriate lifting of water without caring about ground sources. It affects interlinked sources of water table which is declining alarmingly in many areas of Bangladesh. In most cases farmers, do not know the actual amount of water necessary to fulfill the crop needs. Very conventionally, rice farmers everywhere have the tendency of keeping continuous standing water supply in rice fields that results in three dimensional impacts i) wastage of the scarce and vital water resource, ii) increased irrigation cost, and iii) uplifting excess underground water causing environmental degradation [3]. But some earlier studies on water 
management practices for rice production indicated that the application of irrigation water after three days on disappearing of standing water did not reduce rice yield in Boro season (local variety of rice) [21]. It is reported that the Barind region is now in an acute state of deforestation, as a results of the scarcity of surface water sources and low rainfall [11]. Frequent shortage of water in the region poses serious economic, social and environmental impacts [27; $23 ; 13]$. Excessive heats (around 42 degrees $C$ ), hail stones rain, thunderstorms, lightning without rain, uncertain floods, and droughts are very common natural hazards that affect human life and agricultural practices. The present study aims to find out the environmental challenges faced by the farmers in the Barind Tract and the mitigation measures took by the BMDA as a large development partner for sustainable development with healthy environment and high standard of living of the rural people in the Barind Tract.

\section{Research Methods}

\subsection{Theoretical Framework}

In this study, the theoretical framework that used is the economics of strong sustainability [31]. The neo-classical conception of sustainability implies prudent conduct aiming to keep non-diminishing the income [38] that secures a nondiminishing level of consumption in the future. The main condition for sustainability then becomes keeping a nation's productive capacity intact by maintaining its man-made, human, natural, social and technological capital nondiminishing [37]. The fundamental debate regarding sustainability is whether we choose to adopt a "strong" or a "weak" conception of sustainability [31]. Weak sustainability assumes that natural capital and manufactured capital are essentially substitutable [32] and considers that there are no essential differences between the kinds of well-being they generate $[28 ; 30]$. The only thing that matters is the total value of the aggregate stock of capital, which should be at least maintained or ideally increased for the sake of future generations [33]. In addition, from a weak sustainability perspective, technological progress is assumed to continually generate technical solutions to the environmental problems caused by the increased production of goods and services [28].

Authors writing on strong sustainability demonstrate that natural capital cannot be viewed as a mere stock of resources. Rather, natural capital is a set of complex systems consisting of evolving biotic and abiotic elements that interact in ways that determine the ecosystem's capacity to provide humans society directly and/or indirectly with a wide array of functions and services [36, 28, 35]. The researchers demonstrate that natural capital is complementary to manmade capital and constitutes the limiting condition in the total capital frame [34]. From an ecosystem's perspective, a minimum necessary condition of "strong sustainability" is that the total stock of natural capital remains constant over time but this does not state that all ecosystem services everywhere have to be sustained exactly as they are provided that their capacity to renew themselves is conserved [31]. As maintenance of natural capital is essential for practicing sustainable agriculture, this project is based on the strong sustainability theoretical concept.

\subsection{Study Area and Data Collection}

This study emphasizes on the environmental challenges and sustainable development in the Barind Tract in Rajshahi district, Bangladesh, where BMDA started their irrigation projects from the very beginning. Rajshahi district is divided into several zones under BMDA project and the study randomly selected three zones like Puthia, Paba and Godagari zones as the study area. The location map of the study area is shown in Figure 1.

This study used primary as well as secondary data which has been collected from field survey as well as secondary sources to fulfill the objectives. Secondary data has been collected from BMDA head office, zonal offices, government departments, published articles, newspaper reports etc. A short survey technique has been adapted to gather primary data from the key actors of BMDA and the beneficiaries of the selected zones. The field level data has been collected from three selected zones such as Puthia, Paba and Godagari in Rajshahi districts, where BMDA has been operating wide range of development activities. The survey encompassed a questionnaire set made up of both open and close ended questions which tried to find out the environmental challenges faced by farmers and the development activities of BMDA to reduce these environmental challenges and improve the living standard of the people in the study area. Altogether, about 11 officials were purposely selected and invited to participate in the research through distributing hardcopy of the questionnaires. Information was collected from the BMDA Head Quarter and BMDA Zonal office of Puthia, Paba and Godagari zones. For field level survey, this study randomly selected 90 respondents, 30 from each zone and finally interviewed with the help of pre-tested questionnaire of 18 from Puthia, 22 from Paba and 20 from Godagari zone. All respondents were synthesize and used to identify major development activities, environmental challenges and mitigation measures.

\subsection{Data Analysis}

Content analysis is a method that may be used with either qualitative or quantitative data and in an inductive or deductive way [29]. Inductive analysis extracts the concepts from data, where there are no previous studies dealing with the phenomenon, whereas the aim of a deductive approach is to test a previous theory in a different situation or to compare categories at different time periods [29]. In this study, a deductive method has been used to analyze secondary data, but an inductive approach has been used to analyze both qualitative and quantitative primary data in order to identify 
responses to the research questions which could lead to new policies for agricultural and environmental sustainability.

Statistical data which had been collected through surveys and interviews from the beneficiaries has been entered into an electronic data file for analysis, using the IBM Statistical Package for the Social Sciences (SPSS) Edition 23 to calculate frequencies of responses as well as other inferential statistics analysis on categorized data [39]. The Microsoft Office Excel spreadsheet has been used to calculate the average, maximum and minimum value, and to draw figures, charts and tables, etc.

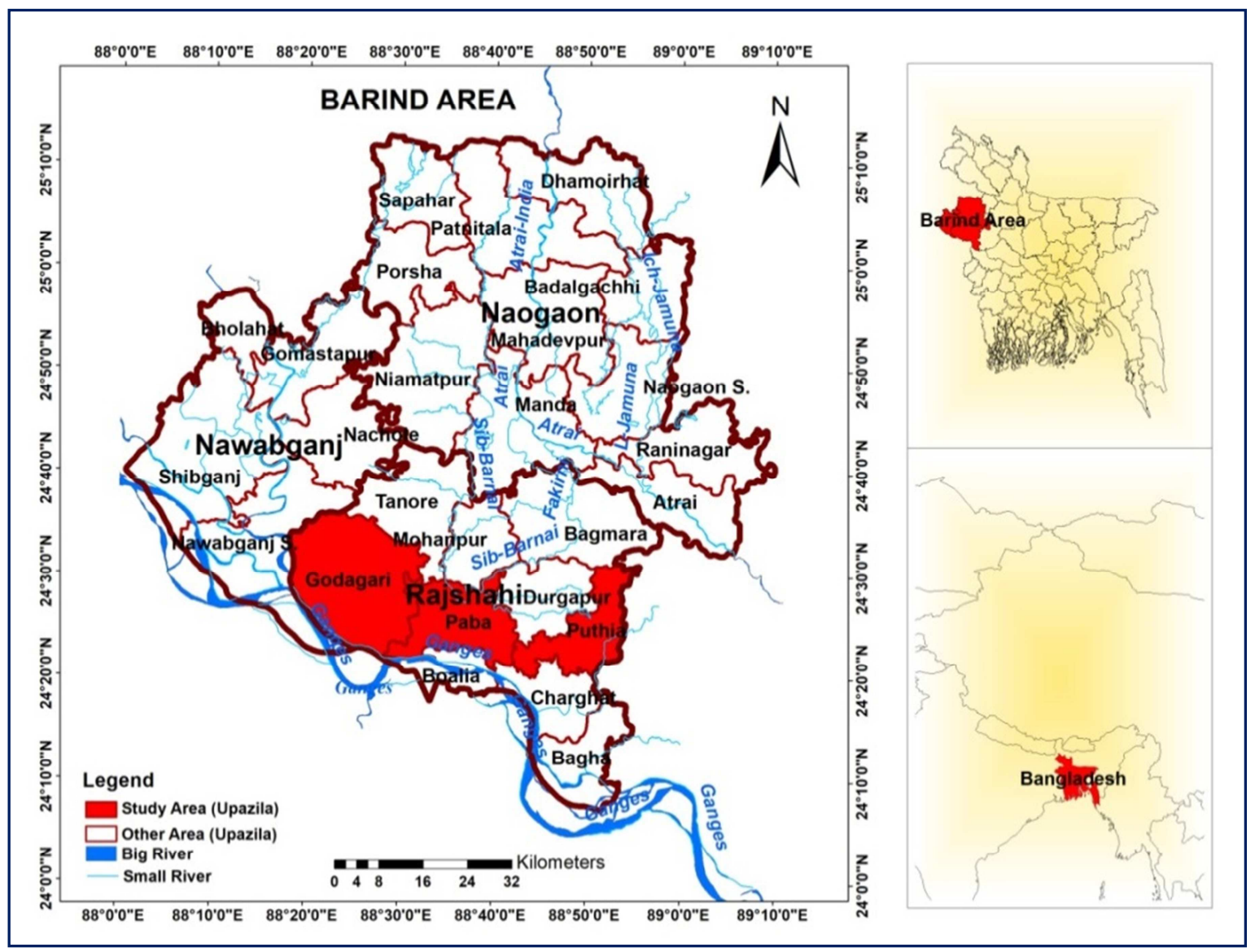

Figure 1. Location Map of the Study Area.

\section{Results and Discussions}

\subsection{Climate Change and Environmental Effects in the Barind Tract}

\subsubsection{Rainfall in the Study Area}

According to the seasonal pattern of Bangladesh, November to February is the winter season and little rainfalls or sometimes no rainfalls occur in this season. Rainy season starts from June and continue to September and huge rainfalls occur in this period. Rainfall data have been collected from the BMDA zonal offices of Puthia, Paba and Godagari Upazilas for the period of 2002 - 2017.

\section{Rainfall in Puthia Zone}

The annual rainfall status is shown in Figure2, where gradual declining trend is found in the study area. Figure 2 shows that maximum annual rainfall was $2,296 \mathrm{~mm}$ in 2007 and the minimum annual rainfall was $528 \mathrm{~mm}$ in 2012 (Appendix, Table 8). Low rainfall means high pressure on ground water and less surface water in canals and rivers which ultimately creates droughts and increases the temperatures. High temperatures, less rainfalls and droughts reduce the crop yields and increase the irrigation costs of the farmers in the study area.

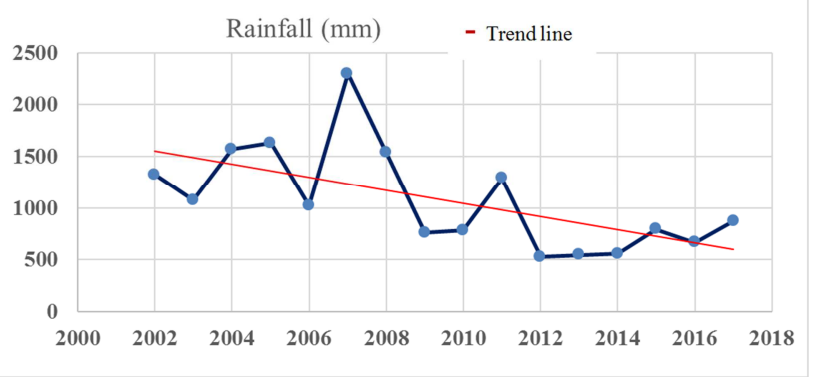

Figure 2. Annual rainfall status of Puthia Zone.

Rainfall in Paba Zone

The fluctuation of rainfall in Paba zone is comparatively lower than that of Puthia zone (Figure 3). The highest rainfall has recorded around $1731.93 \mathrm{~mm}$ in 2004 , which reduced to 
$860.65 \mathrm{~mm}$ in 2010 (Appendix, Table 9). The annual rainfall has declined drastically from 2007 and reached at minimum point in 2010. After 2010, the total rainfall has increased dramatically in 2011 and then declined until 2013. The overall trend shows a straight line indicates a consistent level of rainfall in Paba zone.

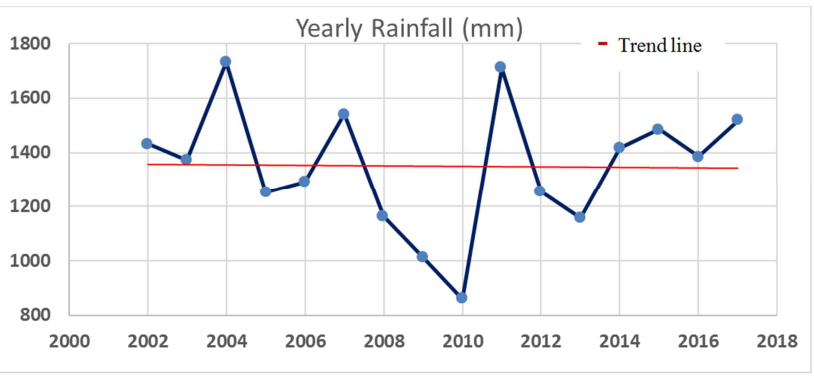

Figure 3. Annual rainfall status of Paba Zone.

\section{Rainfall in Godagari Zone}

Godagari zone is free from flooding and rain water is the only source of recharging ground water. The data has shown that except years $2004(2451.90 \mathrm{~mm})$ and $2015(1710.50$ $\mathrm{mm}$ ), the total rainfalls vary between $848.00 \mathrm{~mm}$ to $1,440.00$ mm (Appendix, Table 10). During 2002 to 2017, the rainfalls were almost zero from November to February and the remaining months had moderate rainfalls (Appendix, Table 10 ), but it is not sufficient for recharge the ground water. It is found from Figure 4 that maximum and minimum annual rainfalls were $2451.9 \mathrm{~mm}$ and $848 \mathrm{~mm}$ in 2004 and 2014 respectively. The overall trend shows a straight line with slight declining trend.

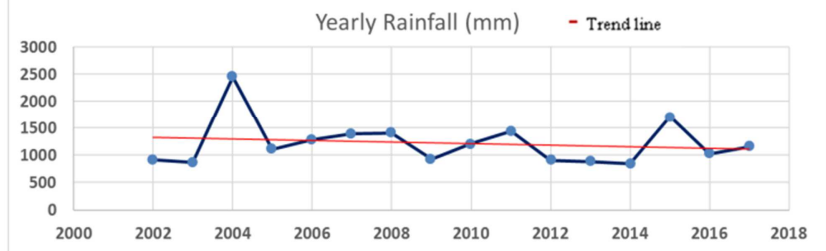

Figure 4. Annual rainfall status of Godagari Zone.

Therefore, the trend of rainfall is declining in Puthia zone, where it is moderate in Paba zone. Though the annual rainfall in Godagari zone is small compare to Puthia and Godagari zones but less fluctuate and consistent compare the other two zones. The declining trend indicates that this area is going to dry day by day and farmers face difficulties to grow crops.

\subsubsection{Level of Groundwater in the Study Area}

There are six seasons in Bangladesh such as Summer, Monsoon, Autumn, Late Autumn, Winter and Spring but people strongly feel Summer (April, May and June), Monsoon (July, August and September) and Winter (November, December, January). Groundwater level fluctuates in different seasons. The data of groundwater level fluctuation has collected from the records of the observation wells $(\mathrm{OW})$ in the Puthia, Paba and Godagari Zonal offices in the period of 1995 to 2017 . The data was available for the $1 \mathrm{st}$ half and 2nd half for the month of January, April, July and October of the respective years. Data are analyzed and presented as the hydrograph.

\section{Groundwater level in Puthia Zone}

Groundwater hydrograph of Puthia Upazila (Figure 5) shows that the groundwater level (GWL) is started to decline from January and reached at maximum level in April in each year (driest month). Some low lands go under water due to flood, indicates ground water and surface water levels are at the same level $(0.00 \mathrm{~m})$.

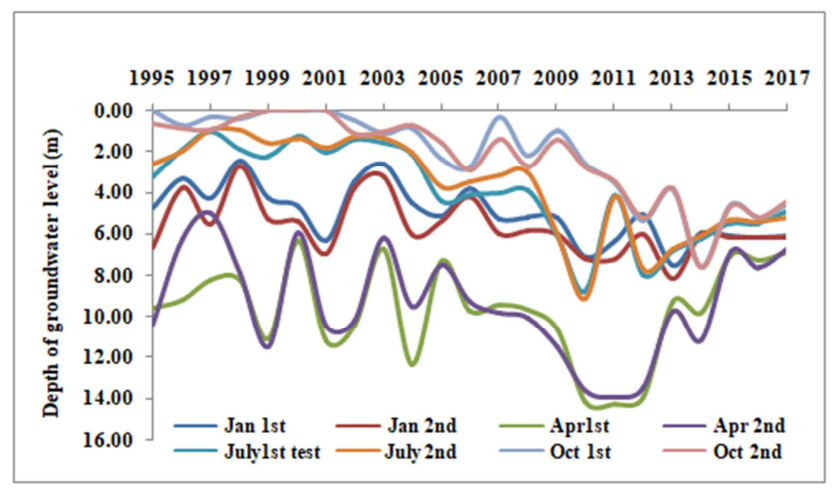

Figure 5. Groundwater level hydrograph for Puthia Upazila.

It is found that in 2010, the level of GWL declined to $14.20 \mathrm{~m}$ in April ( $1^{\text {st }}$ test $)$ and in rainy season the level reduced to $2.59 \mathrm{~m}$ in October ( $1^{\text {st }}$ test). Gradual declination is found from 1995 to 2013 and after that slight rise in water levels are observed until 2017 for all the curves which may be due to less fluctuation of rainfall and rainwater conservation by rubber dam. After 2002, the groundwater was not fully recharged and the minimum water level increases from $0.00 \mathrm{~min} 2001$ to $4.42 \mathrm{~min} 2017$. Therefore, it is found, that the amount of rainfalls in Puthia zone was declining as well as the groundwater level was declining very sharply and reached to maximum depth in March/April/May in 2010 [2]. On the other hand, on an average $5.60 \mathrm{Mm}^{3}$ of water goes out per year to the Ganges from the Barind aquifer of Puthia, Charghat and Bagha areas as base flow [17-18]. So declination of GWL depends on rainfall, temperature, irrigation with loss of groundwater from aquifer to river and water availability in the river. To reduce the pressure of using groundwater, BMDA has started using surface water from rivers and canals, re-excavating canals, ponds and kharies (canal), and constructing rubber dam and cross-dam in the rivers and kharies to reserve water for the dry season.

\section{Groundwater level in Paba Zone}

Groundwater depth hydrograph is shown in Figure 6, where declination of GWL was found from 1997 to 2004 but after that gradual rising trend of GWL is found. It may be due to the less fluctuation of rainfall, due to conservation of rain water in kharies, pond by re-excavation of canal and pond and augmentation of surface water by constructing rubber dam in the nearby Barnoi River at Puthia Upazila. Again GWL depleted to a maximum depth of $21.39 \mathrm{~m}$ in 2010 
(April) due to the lower rainfall. After that GWL rises up again and the minimum GWL was $3.66 \mathrm{~m}$ in 2008 (October).

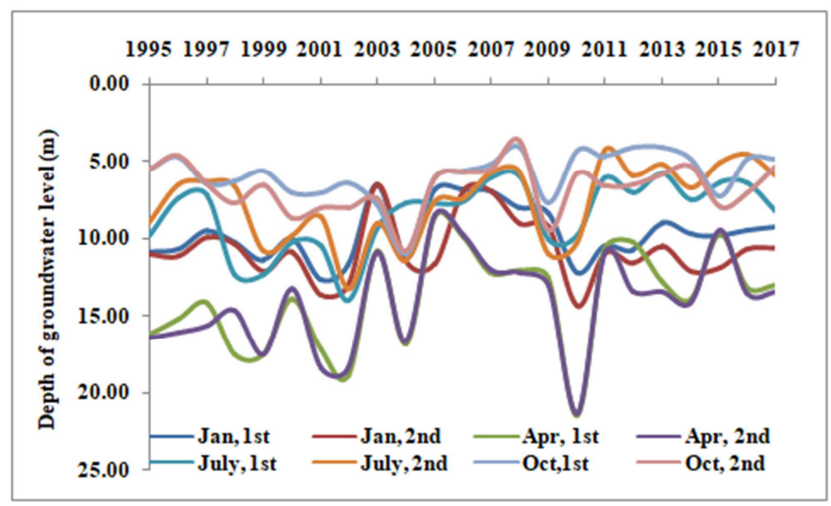

Figure 6. Groundwater level hydrograph for Paba Upazila.

\section{Groundwater Level in Godagari Zone}

The groundwater level situation is more severe in Godagari zone compared to Puthia and Paba zones. Gradual declining trend in GWL is found from the hydrograph (Figure 7) and after 2006 sharp declination is observed which is due to the less and uneven distribution of rainfall, continuous withdrawal of groundwater for irrigation for year round cultivation of 3 to 4 crops, low percolation because of top clay soil, low or no flow in the river Ganges and ground water loss from aquifer to the very nearest Ganges river. It is found that $11.90 \mathrm{Mm}^{3}$ of water goes out per year from aquifer to river and aquifer feeds to the river for 8 months (November - June) and river feeds to aquifer only for 4 months (July - October) [17-18]. The maximum groundwater level in 2015 was $25.89 \mathrm{~m}$ (January) and minimum was 19.54 $\mathrm{m}$ (July). In dry season, the groundwater level is so high that the village people cannot get drinking water from the hand tubewells and due to this reason BMDA starts supplying drinking water to the household level through 130 DTWs. Therefore, the pressure on groundwater is getting increased day by day.

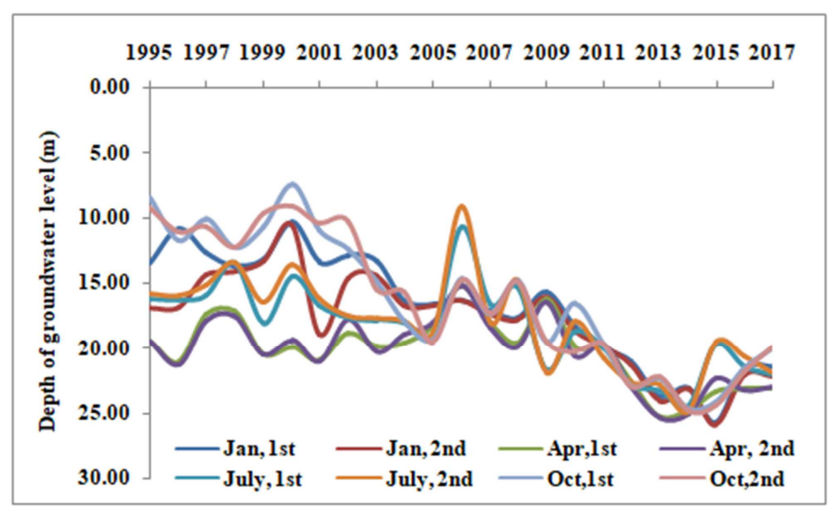

Figure 7. Groundwater level hydrograph for Godagari Upazila.

The depth of groundwater is increasing in Puthia and Godagari zones whereas it is decreasing in Paba zone as it is a low land area and receives moderate rainfall compare to other two zones. Due to high depth of groundwater, the irrigation cost for vegetables and rice is also high in these two areas. In the meantime, BMDA has taken so many steps to use river water, conserve water in the canal and pond for reducing the pressure on groundwater.

\subsubsection{Maximum, Minimum and Average Temperatures $\left({ }^{\circ} \mathrm{C}\right)$ in Rajshahi}

Barind Tract is one of the hottest as well as coldest areas in Bangladesh, whereas the temperatures rise to 42 degrees $C$ in summer and goes down to 4-7 degrees $\mathrm{C}$ in winter. There were extreme temperatures in 2010 and 2019 crossed 40 degrees $\mathrm{C}$ (Figure 8). High temperature is related to other environmental issues like cyclone, tornado, thunderstorms, lightning etc. which sometimes reduce the crop yield. High temperatures increase the intensity of irrigation of the summer crops which ultimately creates pressure on ground water. Due to these extreme temperatures rice, lentils and vegetable production hampered and farmers face losses because of high irrigation cost and bad harvest.

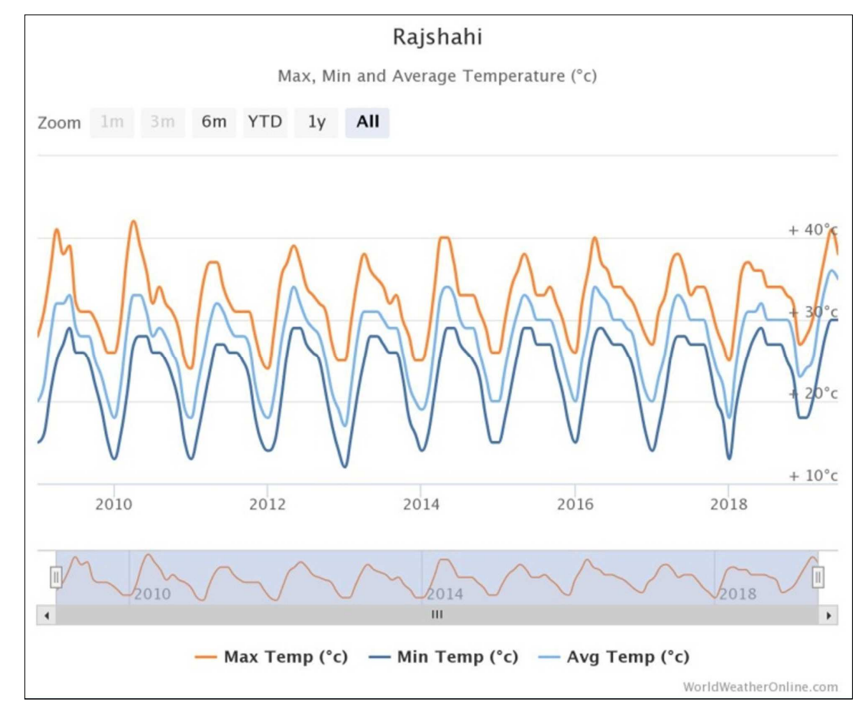

Source: WorldWeatherOnline.com, Accessed on July 1, 2019.

Figure 8. Maximum, Minimum and Average Temperatures $\left({ }^{\circ} \mathrm{C}\right)$ in Rajshahi.

\subsubsection{Environmental Problems Identified by Respondents in the Study Area}

High temperatures and less rainfall are the general features since long ago in the Barind Tract. The existing high temperatures and less rainfall with the extraction of groundwater for irrigation by DTWs and STWs owned by BMDA and individuals have deteriorated the environmental conditions in the Barind Tract. Though the groundwater irrigation has negative effects on climate change but the groundwater irrigation facilities have significant impacts to change the number of crops grown per year, crop production, and living standard of the people in the study area. In Puthia, Paba and Godagari zones 77.78\%, 59.09\% and $85.00 \%$ respondents, respectively face the scarcity of groundwater in the dry season for farming practices (Table 1). Sometimes they have to depend on DTWs as shallow tubewells (STWs) are not able to extract water from ground level. 
Table 1. Natural Hazards as Identified by Respondents in Puthia, Paba and Godagari Zones (\% of total respondent).

\begin{tabular}{llll}
\hline Environmental Impacts & Puthia Zone, \% & Paba Zone, \% & Godagari Zone, \% \\
\hline Scarcity of Water in Summer Season & 77.78 & 59.09 & 85.00 \\
High Temperature & 66.67 & 68.18 & 70.00 \\
Less Rainfall & 33.33 & 77.27 & 40.00 \\
Increasing Cyclone & 0.00 & 4.55 & 0.00 \\
Thunderstorm/lightning & 38.89 & 45.45 & 15.00 \\
Drought & 61.11 & 72.73 & 75.00 \\
\hline
\end{tabular}

Source: Field Survey, 2018, Author's Own Calculation.

The respondents in Puthia (66.67\%), Paba (68.18\%) and Godagari $(70.00 \%)$ zones are experienced high temperatures through desertification due to groundwater declination, narrow flow of water in the major rivers in the dry season because of upstream withdrawal of river water and lack of rainfalls [5]. Drought is a serious problem in the Barind Tract as indentified by $61.11 \%$ (Puthia zone), $72.73 \%$ (Paba zone) and $75.00 \%$ (Godgari zone) of the respondents and sometimes geographers, ecologists and environmental specialists warn that there is evidence of desertification in Barind Tract in the near future [5] (Table 1). Scanty rainfall is another serious problem in the Barind Tract as identified by $33.33 \%, 77.27 \%$ and $40.00 \%$ of the respondents in Puthia, Paba and Godagari zone respectively which is responsible for shortage of surface water and high depth of groundwater table. On the other hand, inadequate rainfall leads to higher dependency on groundwater. Due to high temperature, Rajshahi division is more frequently attacked by thunderstorm and lightning and lots of people lost their lives and injured $[4 ; 14-15]$. Though very few respondents identified thunderstorms and lightning as natural hazards but day by day the risks is getting higher and higher.

\subsection{Development Activities by BMDA in the Study Area}

\section{Puthia Zone}

There are 9 zones in Rajshahi district under the BMDA and Puthia zone is one of them located in Puthia Upazila (sub-district). The whole Puthia zone is basically famous for crops, vegetables and fruits production. Till 2017, Puthia zone has installed 170 deep tubewells, where 168 are operable. The Puthia zone authority has established pre-paid meter to all the deep tubewells, and among these 5 deep tubewells have telemeter system which is controlled by team viewer from the head office. To reduce waste of water, Puthia zone authority has built buried pipe line in all of the project area and they also have decided to supply water through rubber fita pipe, where less water will waste. Under Puthia zone, there are 65 low lift pumps, where 25 low lift pumps are running by solar panel. Among 170 deep tubewells, 49 have facility to supply drinking water to the local households which are managed by local community system (Table 2 ).

Table 2. Integrated Scenario of Important Socio-economic Development by Barind Multipurpose Development Authority in Puthia Zone (2009-2017).

\begin{tabular}{|c|c|c|}
\hline Development Activities & Unit & Amount \\
\hline Total Installation Deep Tubewell (DTW) & Number & 170 \\
\hline Operable Deep Tubewell & Number & 168 \\
\hline Establish Pre-paid meter in DTW & Number & 168 \\
\hline Establish Telemeter in DTW & Number & 5 \\
\hline Construction of Underground Pipe Line & Number & 170 \\
\hline Installation of Low Lift Pump & Number & 65 \\
\hline Low Lift Pump run by Solar Panel & Number & 20 \\
\hline Construction of Infrastructure for Drinking Water & Number & 49 \\
\hline Benefited People from Drinking Water Infrastructure & Person & 13,175 \\
\hline Re-excavation of Khas Khal & Kilometer & 63.36 \\
\hline Construction of Cross Dam for Water Reservoir & Number & 20 \\
\hline Rubber Dam & Number & 1 \\
\hline Surface Water Plant (Padma River-3, Mohananda River-1) & Number & 4 \\
\hline Afforestation & Number & $1,84,000$ \\
\hline Construction of Carpeting Road & Kilometer & 9.92 \\
\hline Construction of Retaining Wall & Meter & 352 \\
\hline Farmer Training & Person & 350 \\
\hline Seed Production and Distribution & Metric Ton & 14 \\
\hline
\end{tabular}

Source: BMDA, Puthia Zone 2018

For conserving water, Puthia zone authority has reexcavated 63.36 kilometer kharies, built 20 cross dams and one rubber dam. For using surface water, Puthia zone has constructed 4 pontoons in Padma and Mohananda rivers which are used to carry water from rivers to canals. To keep weather cool and ecological balance, Puthia zone authority has planted 1,84,000 fruits, wood forest and medicinal trees and 36,000 palm trees for reducing the effects of 
thunderstorm and lightning (Table 2).

Paba Zone

Paba zone is located at Paba upazila in Rajshahi district, which is near to the BMDA head office and Rajshahi city corporation. Paba zone is comprised with high and low land, and yearly 2 to 3 crops are grown in the same land after started the BMDA irrigation project. A total of 278 DTWs are running in Paba zone, where 268 DTWs have pre-paid meter facilities and 10 DTWs have telemeter service (Table 3).

Table 3. Integrated Scenario of Important Socio-economic Development by Barind Multipurpose Development Authority in Paba Zone (2009-2017).

\begin{tabular}{lll}
\hline Development Activities & Unit & Amount \\
\hline Total Installation Deep Tubewell (DTW) & Number & 278 \\
Activating Inoperable DTW & Number & 48 \\
Establish Pre-paid meter in DTW & Number & 268 \\
Establish Telemeter in DTW & Number & 10 \\
Construction of Underground Pipe Line & Number & 132 \\
Construction of Infrastructure for Drinking Water & Number & 49 \\
Benefited People from Drinking Water Infrastructure & Person & 29400 \\
Benefited of Farmers from Deep Tubewell & Person & 15000 \\
Re-excavation of Khas khari & Kilometer & 22 \\
Afforestation & Number & 45000 \\
Palm Tree Plantation & Number & 47500 \\
Construction Carpeting Road & Kilometer & 10.67 \\
Repair Carpeting Road & Kilometer & 15.16 \\
Construction of Retainer Wall & Meter & 350 \\
Farmer Training & Person & 500 \\
Seed Production and Distribution & Metric Ton & 70 \\
\hline
\end{tabular}

Source: BMDA, Paba Zone 2018

Drinking water infrastructures were constructed in 49 DTWs, from where 29,400 people are getting fresh water with cheap cost (BDTk. 7.00 per person, per month, BMDA, 2018). Besides afforestation, Paba zone authority planted palm trees to protect farmers and animals from thunderstorms and lightning. For developing rural communication, BMDA constructs $10.67 \mathrm{~km}$ new and repair $15.16 \mathrm{~km}$ carpeting road. In addition, BMDA trained 500 farmers and produced and supplied $70 \mathrm{Mt}$ seed to the farmers in Paba zone (Table 3).

Godagari Zone

Godagari zone is located in the west part of Rajshahi district, but this zone is different from other areas of Barind Tract, since $80 \%$ agricultural land is hilly sloped (Banglapedia, 2014). Due to hilly slopes, 714 DTWs and 60 LLPs were installed for irrigation purpose (Table 4).

Table 4. Integrated Scenario of Important Socio-economic Development by Barind Multipurpose Development Authority in Godagari Zone (2009-2017).

\begin{tabular}{lll}
\hline Development Activities & Unit & Amount \\
\hline Total Installation Deep Tubewell (DTW) & Number & 714 \\
Establish Pre-paid meter in DTW & Number & 714 \\
Construction of Underground Pipe Line & Number & 714 \\
Installation of Low Lift Pump & Number & 60 \\
Low Lift Pump run by Solar Panel & Number & 24 \\
Construction of Infrastructure for Drinking Water & Number & 130 \\
Benefited People from Drinking Water Infrastructure & Person & 84,500 \\
Benefited Farmers from Deep Tubewell & Person & 38000 \\
Re-excavation of Khas Khal & Kilometer & 397 \\
Construction of Cross Dam for Water Reservoir & Number & 85 \\
Surface Water Plant (Padma River-3 and Mohananda River ${ }^{-1}$ ) & Number & 4 \\
Afforestation & Number & $14,50,000$ \\
Construction of Carpeting Road & Kilometer & 40 \\
Repair of Carpeting Road & Kilometer & 26 \\
Construction of Retainer Wall & kilometer & 17 \\
Farmer Training & Person & 9,700 \\
Seed Production and Distribution & Metric Ton & $3,00,000$ \\
\hline
\end{tabular}

Source: BMDA, Godagari Zone 2018

Among 60 low lift pumps, 24 are running by renewable energy (solar panel) and the remaining LLPs and DTWs are running by electricity. To reduce water loss and increase efficiency, Godagari zone authority constructed buried pipe line to the project area. Through 130 DTWs, 84,500 village people are getting fresh drinking water. For creating water reservoir, Godagari zone re-excavated 397 kilometer Kharies, constructed 85 cross dams and 4 surface water plants. Around 1,450,000 fruits, forests and medicinal trees were planted in the study area through community based 
management to provide income opportunities to the poor people and keep weather condition cool (Table 4).

\subsection{BMDA Facilities Received by Respondents in the Study Area}

Barind Multipurpose Development Authority (BMDA) has a great contribution to change the rainfall dependent, single cropped agricultural land of Barind Tract into the multi cropped land by providing irrigation facilities. It also has made the land well productive and playing a vital role to help achieving national food security. Now, the agricultural pattern, cropping intensity, methods of cultivation, crop variety and yields - all show a positive change. In Paba and Godagari zones, $100 \%$ respondents got irrigation facility, whereas in Puthia zone, $88.89 \%$ respondents got irrigation facility from BMDA. Due to increase in depth of GWL in the dry season, and shortage of water in the shallow and hand tubewells in the dry season, BMDA has started to supply drinking water to the household level through pipeline. Table 5 shows, that $77.78 \%, 22.73 \%$ and $20.00 \%$ respondents in Puthia, Paba and Godagari zones are receiving pure drinking water from BMDA. In the study area, BMDA has reexcavated kharies and supplies water from rivers to the canals through the low lift pumps all over the year. As a result, people of the study area get surface water for irrigation, catch fish and nurturing duck in the canals. Recently, BMDA has re-excavated $30 \mathrm{~km}$ kharies in Puthia zone which is located in the village area and from the field survey it is found that $61.11 \%, 18.18 \%$ and $20.00 \%$ respondents of Puthia, Paba and Godagari zones respectively can catch fish from the canals (Table 5). BMDA started to distribute seeds to the farmers' level and arranged training for them but the respondents of the study area didn't receive any seeds from BMDA and only 5\% respondents in Godagari zone got training from the BMDA authority. BMDA took several projects on tree plantation of the both sides of canals, roads and arable lands, which is managed by community people. Therefore, agencies, owners of the land beside the canals and roads and landless people are the beneficiaries of the tree plantation projects. In Paba zone $77.27 \%$ respondents directly and indirectly got benefit from the tree plantation (Table 5).

Table 5. BMDA Facilities Received by Respondents in the Study Area.

\begin{tabular}{llll}
\hline Facilities/Area & Puthia Zone, \% & Paba Zone, $\%$ & Godagari Zone, $\%$ \\
\hline Get Water for Irrigation & 88.89 & 100.00 & 100.00 \\
Get Water for Household Activities & 77.78 & 22.73 & 20.00 \\
Catch Fish from Canals & 61.11 & 18.18 & 40.00 \\
Farming Duck in the Canals & 55.56 & 18.18 & 30.00 \\
Get Seed from BMDA & 0.00 & 0.00 & 0.00 \\
Get Training from BMDA & 0.00 & 0.00 & 5.00 \\
Get Facilities from Tree Plantation & 22.22 & 77.27 & 25.00 \\
\hline
\end{tabular}

Source: Field Survey, 2018, Author's Own Calculation

\subsection{Socio-economic Impacts of BMDA Projects as Identified by Respondents}

The projects of BMDA have turned out to the blessings for the people of the study area. The rural people of the study area were too poor and they have no much opportunity to earn money and changing their livelihood. But now, the scenario has changed. Table 6 , shows that $100 \%$ of the respondents give their opinions that due to the development projects of the BMDA, crop production, income and employment opportunities have increased. People are busy in crop production all over the year and they no need to migrate in other place for searching job. Though it is not $100 \%$ but large numbers of people in the study area are getting fresh drinking water from BMDA DTWs (Table 6).

Table 6. Socio-economic Impacts of BMDA Projects.

\begin{tabular}{llll}
\hline Socio-economic Impacts/Area & Puthia Zone, \% & Paba Zone, \% & Godagari Zone, \% \\
\hline Increase Income & 100.00 & 100.00 & 100.00 \\
Increase Employment & 100.00 & 100.00 & 100.00 \\
Increase Crop Production & 100.00 & 100.00 & 100.00 \\
Available of Fresh Drinking Water & 77.78 & 22.73 & 15.00 \\
\hline
\end{tabular}

Source: Field Survey, 2018, Author's Own Calculation

\subsection{Measures Taken by BMDA to Improve Environmental Conditions in the Study Area}

BMDA authority has taken decision that they have no plan to install new DTWs in the Barind Tract and they just maintain the existing DTWs for irrigation. By considering the negative impact of over using groundwater, BMDA has been implementing surface water conservation projects aims at lessening the gradually increasing pressure on groundwater for irrigation purposes. The Barind Ttract region is facing water-stress condition, so under the projects, the state-owned derelict canals are being re-excavated to increase the number of reservoirs for drawing rain waters and using it for various purposes.

BMDA has selected three rivers, named Padma, Mohananda and Atrai for diverting the river-water to the canals and further to the farming fields and necessary number of pumps, pontoons and pipelines have been setup in different points (BMDA, 
2018). The experts of BMDA mentioned that increasing the capacity of surface water in dry areas has become essential to reduce dependency on the ground water. Under one project, 16 submerged weirs (cross dam) were constructed for creating surface water reservoir, 38.85 kilometers derelict canals have been re-excavated and 1,23,000 meter underground upvc (unplasticized polyvinyl chloride) pipelines have been commissioned to enhance the irrigation efficiency. Table 7 shows, that $61.11 \%, 59.09 \%$ and $80.00 \%$ respondents in Puthia, Paba and Godagari zone respectively think that reducing use of groundwater is one of the ways to mitigate the environmental hazards. Increasing use of surface water through re-excavated canals has a positive impact on environment and groundwater level which is identified by $77.78 \%, 68.18 \%$ and $85.00 \%$ respondents in the study area (Table 7).

Table 7. Measures Taken by BMDA to Reduce Environmental Impacts answered by respondents (\% of total respondent).

\begin{tabular}{|c|c|c|c|}
\hline Measurements/Area & Puthia Zone, \% & Paba Zone, \% & Godagari Zone, \% \\
\hline Reducing Use of Groundwater & 61.11 & 59.09 & 80.00 \\
\hline Increasing Use of Surface Water & 77.78 & 68.18 & 85.00 \\
\hline Introduce Pre-paid Meter to Reduce waste of water and electricity & 94.44 & 95.45 & 90.00 \\
\hline Construction buried pipe line to reduce waste of land and water & 83.33 & 90.91 & 95.00 \\
\hline Digging Canals & 88.89 & 90.91 & 100.00 \\
\hline Build Dam & 61.11 & 63.64 & 25.00 \\
\hline Digging Well & 0.00 & 9.09 & 5.00 \\
\hline Tree Plantation & 55.56 & 90.91 & 95.00 \\
\hline
\end{tabular}

Source: Field Survey, 2018, Author's Own Calculation.

BMDA has introduced pre-paid meter system in irrigation in 2014 and the system got enormous popularity among farmers in the Barind tract during the last couple of years [22]. The prepaid irrigation system intends to supply irrigation water to the crop field according to farmer's actual demand and this is very helpful to protect meter tempering and checking pilferage of electricity. Pre-paid pump usages and energy measuring unit has been established in 3,900 deep tubewells and more than 82,000 smart cards were distributed among the beneficiary farmers till June 2016. By using prepaid cards farmers are saving at least 30 percent of irrigation costs as well as electricity and misuse of about 40 percent of underground water [22]. This new irrigation system has little environmental impact and the production of crops was increasing due to receiving water for irrigation in due time through pre-paid system. More than $90 \%$ of the respondents of the three zones accepted the pre-paid cards as a way to reduce the waste of water and electricity. The respondents/farmers are getting surface water from canals all over the year for irrigation, since the BMDA has built dams in the canals. Now, the canals are the source of fish and farming duck for the village people. This study found that $100 \%$ of the respondents in Godagari zone gave their opinion that digging canals and use of surface water are the best practices to reduce climate change effects. These canals also use to produce 4,000 metric tons of fish and rearing of 50 million ducks annually, that creates employment opportunities for the day laborers and marginal farmers, and living and livelihood condition of the farmers' community is likely to be improved through crop production (BMDA Implements, 2016). The BMDA projects have provision of transplanting saplings of fruit, forest and herbal tress on both sides of the canals that will ultimately help reduce carbon emissions at a substantial level and that is very important to balance the adverse impact of climate change in the vast Barind tract.

\section{Policy Recommendations and Conclusions}

\subsection{Policy Recommendations}

Agriculture is very important in the context of Bangladesh, because it feeds the large number of population and provides employment of the unskilled and semi-skilled labours in the study area. Due to expansion of groundwater irrigation, cropping intensity, production of crops, employment opportunity and living standard of the rural households in the study area has improved remarkably, but the over extraction of water is considered as the prime reason for groundwater depletion of the study area. After observing the depleting rate of groundwater level in the study area, it can be suggested to fully stop the installation of new DTWs and increase harvesting of rainwater and reserving surface water. More canals and ponds should be re-excavated and necessary steps should be taken to maintain the depth of the canals and ponds all over the year. BMDA should increase the number of low lift pumps which will run by renewable energy (solar panel) for transferring river water to canal and canal to crop field. For infiltration of rainwater into the aquifer, BMDA can install recharge wells scientifically, especially in canal's bed to increase groundwater recharge. Through community management, BMDA can transform the tree plantation program as a movement of the social forestry that will increase the forest resources and help to climate change mitigation and adaptation programs. Planting more palm trees in the Barind tract area can save lives of the farmers from thunderstorm and lightning and keep weather cool. Crop diversification and invention of drought resilient crops help to use less groundwater. To improve efficiency, BMDA should arrange more training for the rural households and 
distribute seeds and fertilizers among the marginal farmers with rational cost.

\subsection{Conclusions}

The BMDA jurisdiction includes 16 districts, which are the major sources of supplying food items and provide employments opportunities in agriculture sector. Without irrigation facility this region will turn to previous situation like poor living condition and one crop region per year in the same land. Therefore, scientific assessment of groundwater resources with zoning for proper planning, artificial recharging, crop diversification, crop zoning, increase cultivation of low water consuming crops, using more surface water, increasing irrigation efficiency, tree plantation, rainwater harvesting, etc. can be options for the mitigation of environmental impacts of this region. Routine maintenance and management of rivers, canals, ponds and other water bodies as reservoirs are also needed for sustainable augmentation of surface water round the year.

\section{Appendix}

Table 8. Rainfall Data (in $\mathrm{mm}$ ) in Puthia Zone.

\begin{tabular}{|c|c|c|c|c|c|c|c|c|c|c|c|c|c|}
\hline Y/D & Jan & Feb & Mar & Apr & May & Jun & Jul & Aug & Sep & Oct & Nov & Dec & Total \\
\hline 2002 & 0.0 & 0.0 & 10.1 & 63.0 & 147.0 & 258.0 & 492.5 & 98.0 & 144.8 & 90.2 & 17.5 & 0.0 & 1321.9 \\
\hline 2003 & 2.6 & 18.0 & 62.0 & 102.0 & 62.5 & 280.4 & 141.3 & 147.9 & 49.9 & 201.0 & 0.0 & 6.0 & 1073.6 \\
\hline 2004 & 22.0 & 0.0 & 0.0 & 59.0 & 80.0 & 422.0 & 232.0 & 54.0 & 590.0 & 114.5 & 0.0 & 0.0 & 1574.1 \\
\hline 2005 & 2.5 & 18.0 & 132.0 & 39.0 & 81.0 & 100.8 & 562.6 & 162.5 & 217.0 & 317.0 & 0.0 & 0.0 & 1632. \\
\hline 2006 & 2.5 & 0.0 & 8.0 & 30.0 & 156.0 & 213.0 & 134.0 & 186.7 & 277.4 & 13.6 & 0.0 & 0.0 & 1021.2 \\
\hline 2007 & 0.0 & 89.0 & 41.0 & 20.0 & 42.0 & 269.0 & 612.0 & 214.0 & 215.0 & 794.0 & 0.0 & 0.0 & 2296.0 \\
\hline 2009 & 0.0 & 4.2 & 6.8 & 0.0 & 92.2 & 74.0 & 135.0 & 222.3 & 199.9 & 29.3 & 0.0 & 0.0 & 763.8 \\
\hline 2010 & 0.0 & 4.9 & 0.0 & 30.0 & 64.2 & 209.2 & 72.9 & 125.0 & 130.0 & 120.0 & 0.0 & 28.5 & 784.7 \\
\hline 2011 & 1.0 & 0.0 & 15.0 & 105.0 & 196.0 & 323.0 & 165.0 & 208.0 & 262.0 & 11.0 & 0.0 & 0.0 & 1286.0 \\
\hline 2012 & 0.0 & 0.0 & 15.0 & 54.2 & 18.0 & 108.0 & 84.7 & 36.8 & 72.0 & 50.0 & 90.0 & 0.0 & 528.7 \\
\hline 2013 & 0.0 & 5.0 & 0.0 & 15.7 & 57.0 & 165.0 & 30.0 & 93.3 & 82.5 & 96.8 & 0.0 & 0.0 & 545.3 \\
\hline 2014 & 0.0 & 10.0 & 0.0 & 17.0 & 44.7 & 162.3 & 76.0 & 115.0 & 113.0 & 23.0 & 0.0 & 0.0 & 561.1 \\
\hline 2015 & 0.0 & 11.0 & 13.0 & 78.2 & 149.0 & 185.0 & 172.0 & 65.0 & 96.0 & 24. & 0.0 & 0.0 & 793.8 \\
\hline 2016 & 11.0 & 7.0 & 7.0 & 15.0 & 166.0 & 66.0 & 194.0 & 74.0 & 75.0 & 51.0 & 0.0 & 0.0 & 666.0 \\
\hline 2017 & 0.0 & 0.0 & 15.0 & 98.5 & 99.0 & 95.0 & 222.5 & 77.0 & 109.0 & 155.0 & 0.0 & 0.0 & 871.0 \\
\hline
\end{tabular}

Source: BMDA, 2018

Table 9. Rainfall Data (in $\mathrm{mm}$ ) in Paba Zone.

\begin{tabular}{|c|c|c|c|c|c|c|c|c|c|c|c|c|c|}
\hline Y/D & Jan & Feb & Mar & Apr & May & Jun & Jul & Aug & Sep & Oct & Nov & Dec & Total \\
\hline 2002 & 0.0 & 1.4 & 20.8 & 87.0 & 197.2 & 225.8 & 316.2 & 237.6 & 281.0 & 48.5 & 17.6 & 0.0 & 1433.1 \\
\hline 2003 & 6.0 & 6.6 & 63.2 & 44.2 & 44.2 & 278.8 & 241.2 & 129.4 & 261.3 & 292.6 & 0.0 & 5.2 & 1372.7 \\
\hline 2004 & 15.0 & 0.0 & 0.0 & 56.5 & 101.6 & 517.0 & 342.7 & 274.0 & 271.9 & 153.2 & 0.0 & 0.0 & 1731.9 \\
\hline 2005 & 0.0 & 0.0 & 100.0 & 104.0 & 103.0 & 91.4 & 146.5 & 161.3 & 276.0 & 272.0 & 0.0 & 0.0 & 1254.2 \\
\hline 2006 & 0.0 & 0.0 & 10.2 & 18.2 & 191.2 & 189.9 & 248.6 & 250.6 & 303.0 & 36.4 & 43.6 & 0.0 & 1291.7 \\
\hline 2007 & 0.0 & 26.5 & 46.8 & 51.6 & 125.8 & 323.1 & 359.4 & 235.7 & 296.9 & 75.4 & 0.6 & 0.0 & 1541.8 \\
\hline 2008 & 31.0 & 0.0 & 0.0 & 30.4 & 144.6 & 244.2 & 223.2 & 241.0 & 127.7 & 121.0 & 0.0 & 0.0 & 1163.1 \\
\hline 2009 & 0.0 & 0.0 & 27.9 & 27.0 & 144.6 & 127.0 & 115.8 & 248.4 & 277.1 & 45.0 & 0.0 & 0.0 & 1012.8 \\
\hline 2010 & 0.0 & 0.0 & 0.0 & 15.0 & 76.0 & 210.5 & 93.7 & 93.7 & 177.0 & 171.7 & 0.0 & 23.0 & 860.6 \\
\hline 2011 & 0.6 & 0.0 & 13.0 & 112.0 & 240.0 & 415.0 & 146.0 & 554.0 & 230.0 & 0.0 & 0.0 & 0.0 & 1710.6 \\
\hline 2012 & 15.0 & 0.0 & 54.0 & 83.0 & 27.0 & 160.0 & 282.0 & 123.0 & 287.0 & 109.0 & 116.0 & 0.0 & 1256.0 \\
\hline 2013 & 2.0 & 28.0 & 0.0 & 5.50 & 146.0 & 189.0 & 126.0 & 208.0 & 139.0 & 315.0 & 0.0 & 0.0 & 1158.5 \\
\hline 2014 & 0.0 & 33.0 & 0.0 & 47.0 & 154.0 & 154.0 & 257.0 & 416.0 & 334.0 & 23.0 & 0.0 & 0.0 & 1418.0 \\
\hline 2015 & 3.0 & 15.0 & 26.0 & 109.0 & 160.0 & 240.0 & 361.0 & 282.0 & 227.0 & 63.0 & 0.0 & 0.0 & 1486.0 \\
\hline 2016 & 35.0 & 5.0 & 66.4 & 50.6 & 156.8 & 157.5 & 354.9 & 227.0 & 208.6 & 124.0 & 0.0 & 0.0 & 1386.2 \\
\hline 2017 & 7.0 & 0.0 & 58.4 & 100.6 & 141.1 & 135.6 & 408.8 & 231.0 & 197.0 & 239.0 & 0.0 & 0.0 & 1518.5 \\
\hline
\end{tabular}

Source: BMDA, 2018

Table 10. Rainfall Data (in mm) in Godagari Zone.

\begin{tabular}{|c|c|c|c|c|c|c|c|c|c|c|c|c|c|}
\hline $\mathbf{Y} / \mathbf{M}$ & Jan & Feb & Mar & Apr & May & Jun & Jul & Aug & Sep & Oct & Nov & Dec & Tot \\
\hline 2002 & 3.0 & 00.0 & 20.0 & 77.0 & 101.0 & 124.0 & 149.0 & 276.0 & 154.0 & 10.0 & 0.0 & 0.0 & 914.0 \\
\hline 2003 & 00.0 & 77.0 & 71.0 & 10.0 & 27.0 & 216.0 & 77.0 & 38.0 & 135.0 & 213.0 & 0.0 & 5.0 & 869.0 \\
\hline 2004 & 5.0 & 0.0 & 0.0 & 349.0 & 360.0 & 612.0 & 195.0 & 99.0 & 552.9 & 279.0 & 0.0 & 0.0 & 2451.9 \\
\hline 2005 & 0.0 & 0.0 & 72.0 & 38.1 & 184.0 & 169.3 & 155.0 & 210.0 & 132.0 & 150.0 & 0.00 & 0.0 & 1110.4 \\
\hline
\end{tabular}




\begin{tabular}{|c|c|c|c|c|c|c|c|c|c|c|c|c|c|}
\hline $\mathbf{Y} / \mathbf{M}$ & Jan & Feb & Mar & Apr & May & Jun & Jul & Aug & Sep & Oct & Nov & Dec & Tot \\
\hline 2006 & 0.0 & 0.0 & 46.0 & 53.3 & 211.0 & 172.0 & 109.0 & 273.7 & 150.0 & 248.0 & 27.0 & 0.0 & 1290.1 \\
\hline 2007 & 0.0 & 22.4 & 0.0 & 0.0 & 270.0 & 195.0 & 214.0 & 120.0 & 335.0 & 234.0 & 0.0 & 0.0 & 1390.4 \\
\hline 2008 & 106.0 & 0.0 & 12.0 & 41.1 & 89.0 & 436.7 & 256.3 & 195.0 & 205.0 & 60.0 & 0.0 & 0.0 & 1401.1 \\
\hline 2009 & 0.0 & 0.0 & 36.0 & 0.0 & 166.0 & 173.0 & 166.0 & 167.0 & 178.0 & 46.0 & 0.0 & 0.0 & 932.0 \\
\hline 2010 & 0.0 & 0.0 & 2.0 & 24.0 & 197.0 & 302.0 & 271.0 & 146.0 & 194.0 & 56.0 & 0.0 & 16.0 & 1208.0 \\
\hline 2011 & 0.0 & 0.0 & 40.0 & 62.0 & 183.0 & 339.0 & 365.0 & 205.0 & 217.0 & 29.0 & 0.0 & 0.0 & 1440.0 \\
\hline 2013 & 0.0 & 18.0 & 0.0 & 0.0 & 37.0 & 125.0 & 164.0 & 251.0 & 102.0 & 188.0 & 0.0 & 0.0 & 885.0 \\
\hline 2014 & 0.0 & 8.0 & 0.0 & 2.0 & 74.0 & 120.0 & 165.0 & 231.0 & 218.0 & 30.0 & 0.0 & 0.0 & 848.0 \\
\hline 2015 & 0.0 & 9.0 & 30.0 & 174.0 & 200.0 & 355.0 & 582.0 & 161.0 & 167.0 & 37.00 & 0.0 & 0.0 & 1710.5 \\
\hline 2016 & 12.0 & 20.0 & 26.0 & 66.0 & 54.0 & 129.0 & 363.0 & 179.0 & 153.0 & 23. & 0.0 & 0.0 & 1025.0 \\
\hline 2017 & 3.0 & 0.0 & 45.0 & 77.0 & 125.0 & 121.0 & 255.0 & 241.0 & 141.0 & 147.0 & 0.0 & 0.0 & 1155.0 \\
\hline
\end{tabular}

Source: BMDA, 2018

\section{References}

[1] Ahmed, K. M. (2006). "Barind Tract," 2006. Banglapedia, National Encyclopedia of Bangladesh. Retrieved from: http://www.banglapedia.org/httpdocs/HT/G_0209.HTM

[2] Ahmeduzzaman, M., Kar, S. and Asad, A. (2012). A study on ground water fluctuation at Barind Area, Rajshahi. Engineering Research and Applications (IJERA), 2 (6), pp1465-1470.

[3] Alam, M. S., Islam, M. S., Salam, M. A. and Islam, M. A. (2009). Economics of alternative wetting and drying method of irrigation: Evidences from farm level study. The Agriculturists, 7 (1\&2), pp. 82-89.

[4] Al Jazeera (2016, May 14). Lightning strikes leave 40 dead in Bangladesh. News/Asia. https://www.aljazeera.com/news/2016/05/lightning-strikesleave-40-dead-bangladesh-160514084057960.html

[5] Ali, M. S. (2007, Jan 19). Desertification: Slow onset of an irreversible disaster. The Daily Star, 5 (939). http://archive.thedailystar.net/2007/01/19/d701191801113.htm

[6] BADC (Bangladesh Agricultural Development Corporation), (2020). Minor Irrigation Survey Report 2018-2019. Government of the People's Republic of Bangladesh, Ministry of Agriculture Banglapedia (2014). Barind Track. National Encyclopedia in Bangladesh. Retrieved from: http://en.banglapedia.org/index.php?title=Barind_Tract

[7] BMDA (2018). Development Activities. Monthly Report FY 2017-2018. Barind Multipurpose Development Project (BMDA), Rajshahi, Bangladesh.

[8] BMDA Implements (2016). BMDA implements surface water conservation project in Barind tract. The Daily Sun, Dhaka, Bangladesh.

[9] Brandon, C. (2018). Toward Sustainable water use for irrigation in Barind Tract, Rajshahi, northwest Bangladesh.

[10] BWDB (1989). Report on Groundwater Field Investigation of the Barind Integrated Area Development Project. Bangladesh Water Development Board Rajshahi, Vol. 1, Main Report.

[11] Dey, N. C., Bala, S. K., Islam, R. S., Shopan, A. A. and Rashid, A. (2015). Environmental and Economic Sustainability of Groundwater for Irrigation: Implications for
Ensuring Food Security in the Northwest Region of Bangladesh. BRAC research and Evaluation Division, BRAC Centre, Dhaka, Bangladesh.

[12] Dey, N. C. and Ali, A. R. M. M. (2010). Changes in the use of safe water and water safety measures in WASH intervention areas of Bangladesh: a midline assessment. Dhaka: BRAC (RED workingpaper-27).

[13] Dey, N. C., Alam, M. S., Sajjan, A. K., Bhuiyan, M. A., Ghose, L. Ibaraki, Y. and Karim, F. (2011). Assessing environmental and health impact of drought in the northwest Bangladesh. Journal of Environmental Science and Natural Resources. 4 (2): pp.89-97.

[14] Dhaka Tribune (2019, July 6). Reports: Lightning kills 126 in May-June. Dhaka Tribune.

https://www.dhakatribune.com/bangladesh/2019/07/06/reportlightning-kills-126-in-may-june

[15] Dhaka Tribune (2018, May 22). Lightning strikes kills 200 people in 75 days. Dhaka Tribune. Retrieved from: https://www.dhakatribune.com/bangladesh/nation/2018/05/22/ lightning-strikes-kill-200-in-75-days

[16] Hossain, M. I., Bari, N., Miah, S. U. (2019). Operational Constraints in Conventional Managed Aquifer Recharge in Barind Area at North-Western Region of Bangladesh. Proceedings of $2^{\text {nd }}$ International Conference on Planning, Architecture \& Civil Engineering, Faculty of Civil Engineering, Rajshahi University of Engineering \& Technology, Rajshahi, 07-09 February.

[17] Imon, A. H. M. R. and Ahmed, M. (2013). Water Level Trend in Barind Area. (Malaysian Journal of Mathematical Sciences, 7 (1), pp (1-15).

[18] IWM (2006) Groundwater Model Study for Deep Tubewell Installation Project in Barind Area. Final Report, Volume I.

[19] IWM, (2012). Groundwater Resources Study and Decision Support System Development of Rajshahi, Naogaon, Chapai Nawabganj, Pabna and Natore Districts and Also Remaining District of Rajshahi Division through Mathematical Model Study for Barind Integrated Area Development Project, PhaseIII, Final Report, Volume I.

[20] Jahan, C. S. (1997). Origin and Occurrence of Groundwater in Barind Area (Bangladesh) and Prospects of its Utilization. Unpublished Thesis, Moscow State Geological Prospecting Academy, Moscow. 
[21] Jahan, C. S., Mazumder, Q. R., Akter, N., Adham, M. I. and Zaman, M. A. (2010). Hydrogeological environment and groundwater occurrences in the pliopleistocene aquifer in Barind area, northwest Bangladesh. Bangladesh Geoscience Journal, 16, pp. 23-37.

[22] Kasem, M. A. (2006). Evaluation of water management practices for different methods of rice production. PhD thesis. Faculty of Agricultural Engineering and Technology, Mymensingh: Bangladesh Agricultural University.

[23] Pre-paid Irrigation Card (2016). Prepaid Irrigation Card getting Popularity. Dhaka Tribune. Retrieved from: https://www.dhakatribune.com/bangladesh/2016/08/20/prepaid-irrigation-card-getting-popularity

[24] Rasheed, K. B. S. (2008). Bangladesh: Resource and Environmental Profile, A. H. Development Publishing House, Dhaka, 2008).

[25] Sajjan, A. K., Bhuiyan, M. A. and Dey, N. C. (2002). Impact of 1994-1995 drought in the northwest of Bangladesh through questionnaire survey. In proc. of the $2^{\text {nd }}$ annual paper meet of Ag. Eng. Division, Institution of Engineers, Bangladesh: 31 (5).

[26] Sarkar, FIMGW, Biswas, J. C. and Moniruzzaman, M. (2014). Climate Change Adaptation and Economic Profitability: Crop Land Shifting to Mango Orchard in Rajshahi Region. Bangladesh Rice Journal 18 (1 \&2): pp 8-17.

[27] Shahid, S and Behrawan, H. (2008). Drought risk assessment in the western part of Bangladesh. Journal of Natural Disaster. Nat Hazzards. 46: pp. 391-413. Doi: 10.1007/s1069-0079191-5.

[28] Shahid, S. (2008). Spatial and Temporal Characteristics of Droughts in the Western Part of Bangladesh. Hydrol Process 22: pp. 2235-2247, doi: 10.1002/hyp.6820.

[29] Takara, K. and Ikebuchi, S. (1997). Japan's 1994 drought in terms of drought duration curve. Proc. of the fifth symposium of Water Resources: pp. 467-77.

[30] Ekins, P., Simon, S., Deutsch, L., Folke, C., De Groot, R. (2003). A framework for the practical application of the concepts of critical natural capital and strong sustainability. Ecological Economics, 44, 165-185.

[31] Elo, S. and Kyngas, H. (2008). The qualitative content analysis process. Journal of Advance Nursing, 62 (1), pp. 107105. doi: $10.1111 /$ j.1365-2648.2007.04569.x.
[32] Neumayer, E. (2003). Weak versus strong sustainability: exploring the limits of two opposing paradigms. Edward Elgar, Northampton.

[33] Pelenc, J. Ballet, J. and Dedeurwaerdere, T. (2015). Weak sustainability versus strong sustainability. https://sustainabledevelopment.un.org/content/documents/656 9122-

PelencWeak\%20Sustainability\%20versus\%20Strong\%20Susta inability.pdf

[34] Solow, R. M. (1974). 'Intergenerational equity and exhaustible resources', Review of Economic Studies, Symposium on the Economics of Exhaustible Resources, (14), pp.29-45.

[35] Solow, R. (1993). Sustainability: an economist's perspective. Dorfman, N. and Dorfman, R. (Eds.), Selected readings in environmental economics. Norton, New York (1993), pp.179189.

[36] Daly, H. and Farley, J. (2014). Ecological Economics. Island Press.

[37] Brand, F. (2009). Critical natural capital revisited: Ecological resilience and sustainable development. Ecological Economics, 68, 605-612.

[38] Noël, J-F., O'Connor, M. (1998). Strong Sustainability and Critical Natural Capital. In: Faucheux, S., O'Connor, M., (Eds.), Valuation for Sustainable Development: Methods and Policy Indicators. Edward Elgar, pp. Publisher, Cheltenham 75-99.

[39] Ayres, R.; van den Bergh, J. and Gowdy, J. (2001). Viewpoint: Weak versus Strong Sustainability, Environmental Ethics, 23: pp. 155-168.

[40] Hicks, J. R. (1946). The value of Capital, $2^{\text {nd }}$ edition, Oxford: Oxford University Press.

[41] Evans, S. (2017). Transition to a sustainable food system in Newfoundland and Labrador: The promise of organic agriculture (Master thesis). Environmental Policy Institute. Memorial University of Newfoundland, Canada.

[42] Rahman, M. M. and Mahbub, A. Q. M. (2012). Groundwater Depletion with Expansion of Irrigation in Barind Tract: A Case Study of Tanore Upazila. Journal of Water Resource and Protection, 4, pp. 567-575. 